\title{
Case Report: Celiac Disease Mimicking Cystic Fibrosis
}

\section{Olgu Sunumu: Kistik Fibrosisi Taklit Eden Çölyak Hastalığı}

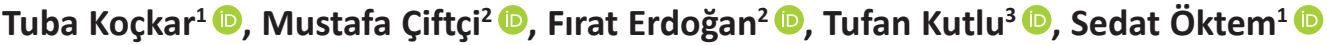

${ }_{1}^{1}$ Istanbul Medipol Üniversitesi, Tıp Fakültesi, Çocuk Göğüs Hastalıkları Bilim Dalı, İstanbul, Türkiye

${ }^{2}$ İstanbul Medipol Üniversitesi, Tıp Fakültesi, Çocuk Sağlığı ve Hastalıkları Ana Bilim Dalı, İstanbul, Türkiye

${ }^{3}$ İstanbul Üniversitesi, Cerrahpaşa Tıp Fakültesi, Çocuk Sağlığı ve Hastalıkları Anabilim Dalı, Çocuk Gastroenteroloji ve Hepatoloji Bilim Dalı, İstanbul, Türkiye

ORCID ID: T.K. 0000-0002-6819-3887; M.Ç. 0000-0001-9351-7102; F.E. 0000-0003-1123-4729; T.K. 0000-0001-8396-4048; S.Ö. 0000-0002-7950-2067

Citation/Attf: Kockar T, Ciftci M, Erdogan F, Kutlu T, Oktem S. Case report: celiac disease mimicking cystic fibrosis. Çocuk Dergisi - Journal of Child 2021;21(1):83-85. https://doi.org/10.26650/jchild.2021.776073

\section{ABSTRACT}

In this report, a ten-year-old boy was presented with a history of chronic diarrhea, recurrent wheezing, recurrent respiratory infections, finger clubbing, and growth retardation. Due to bronchiectasis in the chest tomography, low gaita elastase levels, and symptoms and signs of the case, the patient was diagnosed with cystic fibrosis at first. Nevertheless, since the patient's response to enzyme replacement therapy was poor, sweat test results detected at intermediate levels, and gene analysis of cystic fibrosis-associated mutations were not found. A further evaluation was performed for a differential diagnosis, and Celiac disease was the final diagnosis of the patient.

Our paper highlighted that patients with cystic fibrosis symptoms should be evaluated further for Celiac disease, especially in cases resistant to standard cystic fibrosis treatment. Thus, Celiac disease must be kept in mind in differential diagnoses of cystic fibrosis patients resistant to therapy or in conditions in which cystic fibrosis diagnosis is not certain.

Keywords: Cystic fibrosis, Celiac disease, differential diagnosis

\section{INTRODUCTION}

Celiac Disease $(C D)$ is a relatively common chronic severe gastrointestinal disorder characterized by chronic diarrhea, malnutrition, abdominal distention, and failure to thrive, which are also common symptoms of cystic fibrosis (CF) $(1,2)$. The coincidence of $\mathrm{CF}$ and $\mathrm{CD}$ has been reported in nineteen cases previously; moreover, in some cases, these diseases may mimic each other (3).

\section{CASE REPORT}

A ten-year-old Libyan boy was admitted to our hospital with complaints of chronic diarrhea, wheezing, recurrent respiratory öz

Bu yazıda kronik ishal, tekrarlayan hışıltılı solunum atakları, sık solunum yolu enfeksiyonu, parmaklarda çomaklaşma ve büyüme geriliği bulunan 10 yaşında bir olgu sunulmuştur. Vakanın semptom ve bulguları, akciğer tomografisinde bronşiektazi saptanması, düşük dışkı elastaz seviyeleri nedeni ile başlangıçta kistik fiboz tanısı düşünülmüştür. Ancak, hastanın enzim replasman tedavisine yanıtının düşük olması, ter testi sonuçlarının orta düzeyde olması ve gen analizinde kistik fibroz ilişkili mutasyonların saptanmaması nedeniyle ayırıcı tanılar için ileri incelemeler yapılmış ve hastaya Çölyak hastalığı tanısı konmuştur.

Makalemizde, özellikle kistik fibroz tedavisine dirençli kistik fibroz bulguları olan hastaların Çölyak hastalığı açısından ileri incelenmesinin gerekliliği vurgulanmıştır. Diğer bir deyişle, Çölyak hastalığı, kesin kistik fibrozis tanısı konulamayan veya enzim replasman tedavisine dirençli kistik fibroz tanılı hastalarda ayırıcı tanıda düşünülmelidir.

Anahtar Kelimeler: Kistik fibrozis, Çölyak hastalığı, ayırıcı tanı

infections, and stunted growth. His birth weight was 3500 grams. At 5 months of age, he experienced diarrhea, wheezing, and poor weight gain. He was hospitalized for pneumonia and asthma once and used antibiotics, inhaled salbutamol, and budesonide several times. A physical examination revealed diminished subcutaneous fat tissue and muscle mass, finger clubbing, fine rales in the lungs bilaterally (especially in the right lung), and wheezing with respiratory distress. His weight and height were both lower than the $3^{\text {rd }}$ percentile of his age. An abdominal examination revealed marked abdominal distension but no hepatosplenomegaly, palpable masses or ascites. The rest of the examination was unremarkable. The initial laboratory investigations were as follows: hemoglobin $10.1 \mathrm{~g} / \mathrm{dL}$, mean

Corresponding Author/Sorumlu Yazar: Mustafa Çiftçi E-mail: drciftci@gmail.com

Submitted/Başvuru: 05.08.2020 • Revision Requested/Revizyon Talebi: 14.01.2021 • Last Revision Received/Son Revizyon: 22.01 .2021 • Accepted/Kabul: 02.02.2021 
corpuscular volume 76 femtoliters, red cell distribution width $20.7 \%$, ferritin $6 \mathrm{ng} / \mathrm{mL}$, albumin $3.1 \mathrm{~g} / \mathrm{dL}, 25(\mathrm{OH})-\mathrm{D}_{3}$ vitamin $14.5 \mathrm{ng} / \mathrm{L}$ (range 30-80). Vitamin B12, folate, total protein, aspartate aminotransferase (AST), alanine aminotransferase $(A L T)$, and alkaline phosphatase (ALP) were within normal ranges. The immunoglobulin G2 (IgG2) level was low $(66.4 \mathrm{mg} /$ $\mathrm{dL}$ ) but other immunoglobulins (Ig) were within normal ranges (IgM: 162 mg/dL, IgA: 170 mg/dL, IgG: 742 mg/dL, IgG1: 639 $\mathrm{mg} / \mathrm{dL}$, IgG3: $51.8 \mathrm{mg} / \mathrm{dL}$, IgG4: $21.7 \mathrm{mg} / \mathrm{dL}$ ). Fecal elastase-1 concentration was detected at $104 \mathrm{mcg} / \mathrm{gr}$ stool (normal level $>200$ mcg/gr stool, mild deficiency $100-200 \mathrm{mcg} / \mathrm{gr}$ stool and severe deficiency $<100 \mathrm{mcg} / \mathrm{gr}$ stool). There was a honey comb appearance on the chest $\mathrm{x}$-ray, and parabronchial infiltration and bronchiectasis were seen in the right middle lobe and left lingual segment on chest computed tomography (Figures 1 and 2). The abdominal ultrasonography and echocardiography were reported as normal. Sweat tests were detected as follows: 54 , 65 , and $62 \mathrm{mmol} / \mathrm{L}$ by conductivity method.

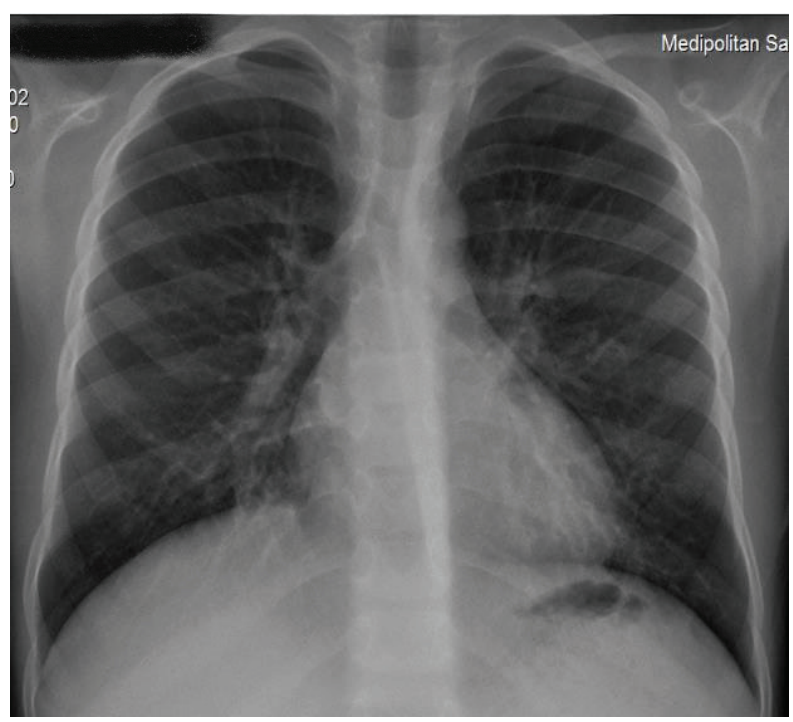

Figure 1: Honey-comb appearance in right middle lobe on chest x-ray.

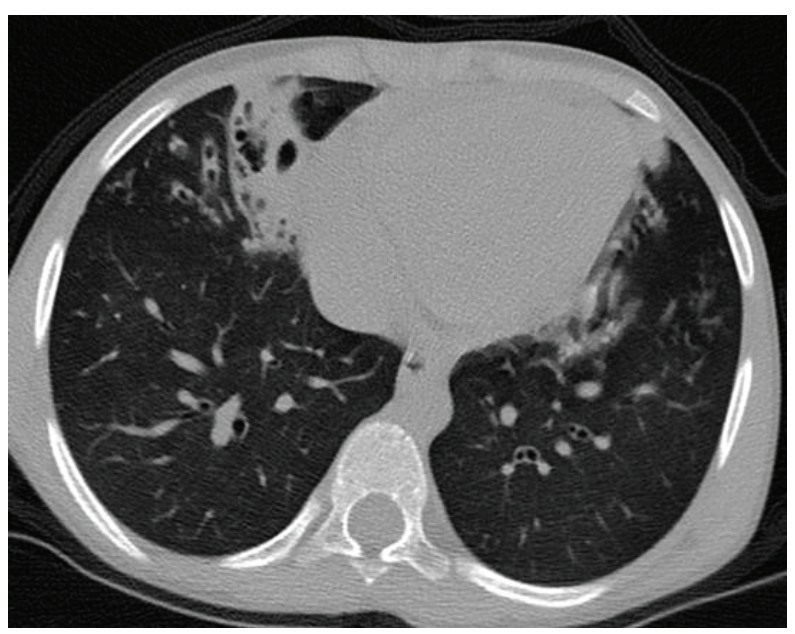

Figure 2: Parabronchial infiltration and bronchiectasis in right middle lobe and left lingual segment on HRCT of thorax.
According to laboratory and imaging findings and the symptoms and signs of the patient, he was diagnosed with cystic fibrosis, and a regiment of antibiotics, inhaled salbutamol and budesonide, dornase alpha, pancreatic enzyme, and vitamin treatments was begun. After that, the cough, rales, and respiratory distress improved. He gained weight, and his diarrhea decreased. However, due to unresolved abdominal distension and sweat analysis detecting at intermediate levels, coeliac disease was considered in the differential diagnosis. A biochemical screening was performed, and the results showed anti-gliadin IgG $160 \mathrm{U} / \mathrm{mL}$ (negative screen <20 U/ $\mathrm{mL}$ ), anti-gliadin $\lg A>200 \mathrm{U} / \mathrm{mL}$ (negative screen $<20 \mathrm{U} / \mathrm{mL}$ ), anti-endomysium IgA $>200$, and anti-endomysium IgG negative. Thus, the patient underwent an endoscopic examination, and an intestinal biopsy was performed to investigate CD. In the biopsy specimen, total villus atrophy and increased intraepithelial lymphocytosis indicating $C D$ were reported. After a gluten-free diet without pancreatic enzyme replacement, diarrhea ceased, and the patient's weight was increased. Also, the fecal elastase- 1 concentration increased to $224 \mathrm{mcg} / \mathrm{gr}$. HLA $\mathrm{DQ} 2$ positive results were thought consistent with $\mathrm{CD}$. There was no CF associated mutation found in the gene analysis.

\section{DISCUSSION}

We represent a 10 -year-old boy diagnosed with $C D$, whose symptoms mimicked CF. In our case, non-specific symptoms like growth-development delay, short stature, anemia, and diarrhea, symptoms mimicking CF (for instance, coughing, respiratory distress, and frequent respiratory infections) were present. Several factors such as diabetes, CD, exocrine pancreatic insufficiency, and chronic lung inflammation may lead to CF-like symptoms (4). In our case, beyond the symptoms of the patient, bronchiectasis was detected on chest tomography. Cystic fibrosis could result in bronchiectasis, but there are also other diseases that may lead to bronchiectasis, such as primary ciliary dyskinesia, a post-infectious bronchiectasis, allergic bronchopulmonary aspergillosis, immunodeficiencies, aspiration of foreign substances, etc (5). Additionally, different CFTR gene mutations result in different disease phenotypes. Some may have little or no effect on CFTR function and may result in milder forms of the disease (3). In our case, at first, it was thought that bronchiectasis was a consequence of CF. However, the results of the sweat tests and gene analysis were not consistent with $\mathrm{CF}$, and with further investigations, it was found that the reason of bronchiectasis was IgG2 deficiency.

Atypical manifestations of $C D$ have been reported as isolated anemia, osteoporosis, short stature, peripheral neuropathy, rickets, constipation, and delayed puberty (3). Another issue in $C D$ is the comorbidity with other diseases which may delay appropriate interventions. For example, CD and CF have shared a number of clinical manifestations recognized as one clinical entity for many years. In addition, patients with CF alone may have similar symptoms with $C D$, such as poor weight gain, loose stools, and abdominal pain. It is important to keep in mind that the co-existence of the two diseases in the same patient 
has been reported sporadically $(3,6,7)$. Also, incidence of $C D$ was 3 times increased in CF patients (4). It was suggested that pancreatic insufficiency results in vulnerability of the mucosa of the bowel due to gluten protein contact $(7,8)$. Therefore, shared pathogenesis of both diseases might lead to similar clinical presentations. In addition to screening antibody tests, a duodenal biopsy is essential in order to confirm the diagnosis of CD. In our case, consistent with Marsh's Criteria, the duodenal biopsy revealed intraepithelial lymphocyte infiltration and villous atrophy (1). Increased intestinal inflammation manifests in both disorders. It was suggested that intestinal inflammation, exocrine pancreatic insufficiency leading to protein exposure, and a shorter period of breastfeeding may predispose patients carrying CF genes to $C D(4,6,7)$. In immunological tests, positive TTG IgA was reported in CF patient comorbid with CD, followed by positive findings in a duodenal biopsy $(4,6,7)$. Inflammatory markers like eosinophilic cationic protein and neutrophil elastase increased in children with CF. Moreover, it was suggested that low gaita elastase levels are found in $C D(8)$. We determined that the clinical symptoms were due to $C D$ because the patient recovered only after gluten-free diet was started.

In conclusion, although the criteria have been generally specified, there is still no consensus as to when children with CF should be evaluated for CD (9). It might be reasonable to screen CF patients whose symptoms are resistant to standard treatment for CD. Thus, CD must be thought in differential diagnoses in CF cases resistant to enzyme replacement therapy or if the diagnosis is not certain.

Bilgilendirilmiş Onam: Kathlımcılardan bilgilendirilmiş onam alınmıştır

Hakem Değerlendirmesi: Dış bağımsız.

Yazar Katkıları: Çalışma Konsepti/Tasarım- T.K., M.Ç., F.E., T.K., S.Ö.; Veri Toplama-T.K.; Veri Analizi/Yorumlama-T.K., S.Ö.; Yazı Taslağı- M.Ç., F.E.; Içeriğin Eleştirel İncelemesi- T.K., S.Ö.; Son Onay ve Sorumluluk- T.K., M.Ç., F.E., T.K., S.Ö.

Çıkar Çatışması: Yazarlar çıkar çatışması beyan etmemişlerdir.

Finansal Destek: Yazarlar finansal destek beyan etmemişlerdir.
Informed Consent: Written consent was obtained from the participants.

Peer Review: Externally peer-reviewed.

Author Contributions: Conception/Design of Study- T.K., M.Ç., F.E., T.K., S.Ö.; Data Acquisition- T.K.; Data Analysis/Interpretation- T.K., S.Ö.; Drafting Manuscript- M.C.., F.E.; Critical Revision of Manuscript- T.K., S.Ö.; Final Approval and Accountability- T.K., M.Ç., F.E., T.K., S.Ö.

Conflict of Interest: Authors declared no conflict of interest.

Financial Disclosure: Authors declared no financial support.

\section{REFERENCES}

1. Green PH, Cellier C. Celiac disease. N Engl J Med 2007;357:17311743.

2. Orenstein DM, Winnie GB, Altman H. Cystic fibrosis: a 2002 update. J Pediatr 2002;140:156-164.

3. Kostovski A, Zdraveska N. Coagulopathy as initial manifestation of concomitant celiac disease and cystic fibrosis: a case report. J Med Case Reports 2011;5:116.

4. Pohl JF, Judkins J, Meihls S, Lowichik A, Chatfield BA, McDonald $\mathrm{CM}$. Cystic fibrosis and celiac disease: both can occur together. Clin Pediatr (Phila) 2011;50(12):1153-5.

5. Haworth CS, Bilton D, Elborn JS. Long-term macrolide maintenance therapy in non-CF bronchiectasis: evidence and questions. Respir Med 2014;108(10):1397-408.

6. Fluge G, Olesen HV, Gilljam M, Meyerd P, Presslere T, Storrösten OT et al. Co-morbidity of cystic fibrosis and celiac disease in Scandinavian cystic fibrosis patients. J Cyst Fibros 2009;8:198-202.

7. Walkowiak J, Blask-Osipa A, Lisowska A, Oralewska B, Pogorzelski $A, C i c h y$ W et al. Cystic fibrosis is a risk factor for celiac disease. Acta Biochim Pol 2010;57:115-118.

8. Gheorghe C, Seicean A, Saftoiu A, Tantau M, Dumitru E, Jinga $M$, et al. Romanian guidelines on the diagnosis and treatment of exocrine pancreatic insufficiency. J Gastrointestin Liver Dis 2015;24(1):117-123.

9. Genkova ND, Yankov IV, Bosheva MN, Anavi BL, Grozeva DG, Dzhelepova NG. Cystic fibrosis and celiac disease-multifaceted and similar. Folia Med (Plovdiv) 2013;55(3-4):87-89. 